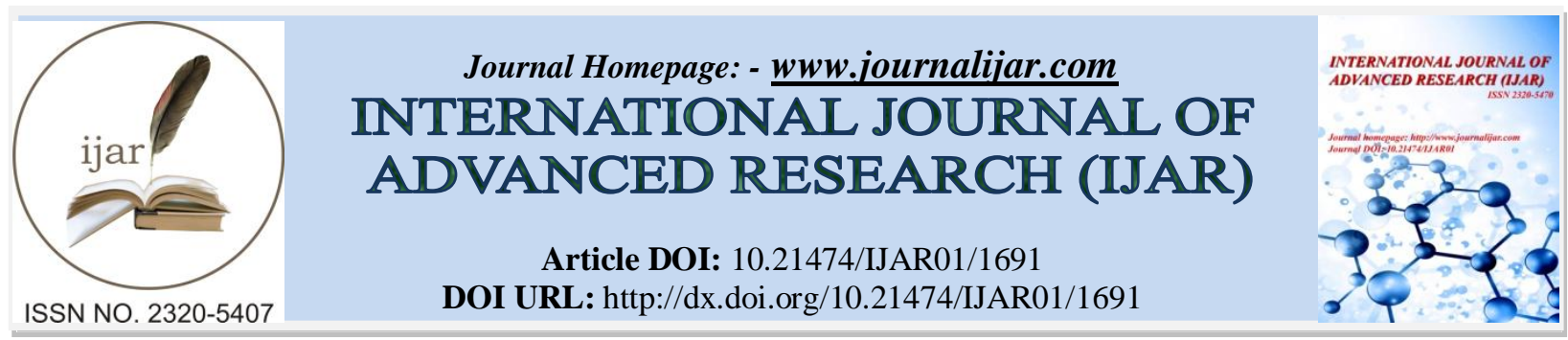

RESEARCH ARTICLE

\title{
DEVELOPMENT OF THE LEGAL FRAMEWORK OF PARLIAMENTARY CONTROL IN UZBEKISTAN: THE MAIN PROVISIONS OF THE LAW "ON PARLIAMENTARY CONTROL"
}

Rahim Rasuljonovich Hakimov.

$\mathrm{PhD}$ in Law, Associate Professor.

\section{Manuscript Info}

Manuscript History

Received: 12 June 2016

Final Accepted: 19 July 2016

Published: August 2016

Key words:-

The principle of separation of powers, checks and balances, the democracy, the legislature, the executive, parliamentary control, constitutional reforms, strengthening the role and oversight powers of Parliament, the subjects of parliamentary control, the objects of parliamentary control, the forms of parliamentary control, the limits of parliamentary control, measures response at the end of the parliamentary control.

\section{Abstract}

The article aims at reviewing the development of the constitutional and legal framework of parliamentary control in Uzbekistan. It will analyze the large-scale, successive reforms aimed at strengthening the role, authority and control functions of the Parliament - the Oliy Majlis of the Republic of Uzbekistan - carried out during the years of independence. Particular attention is paid to the disclosure of the nature and content of the Law "On Parliamentary Control" adopted in 2016. Separately, the issues concerning the subject structure of legal relations in the sphere of parliamentary control, the object of parliamentary control, the permissibility and the limits of parliamentary control, its forms, as well as measures taken by the parliament as a result of the control measures. The paper will attempt to prove theoretical insight into the provisions of the Law of the Republic of Uzbekistan "On Parliamentary Control", identify a number of issues that require theoretical and practical discussion as well as thorough scientific study.

Copy Right, IJAR, 2016,. All rights reserved.

Democratic system of government based on the principle of separation of powers, cannot exist without transparency and accountability of public authorities to the people. This is the essence and the main requirement of democracy, which is the basis of any modern state and its legal system. Consistent implementation of these principles in the field of state-building and social development largely depends on the efficiency of the activities of Parliament, which is directly formed by the people and acts on their behalf.

Realizing its core functions: representative, legislative and control, parliament becomes the most important guarantee that the policy of the government, its actions are effective and commensurate with the needs, the interests of the people and society. At the same time one of the most effective political and legal means to ensure the rule of law, the effectiveness of the executive branch, support the optimal balance between the branches of government is a parliamentary control.

Over the years of independence, Uzbekistan has made consistent and gradual reforms to strengthen the regulatory functions of the Parliament - the Oliy Majlis of Uzbekistan - as an important component of the principle of separation of powers, checks and balances. The main forms of parliamentary control are enshrined in the Constitution since its adoption in 1992. So, in the implementation of fiscal policy has provided such an important form of control as the decision on the proposal of the Cabinet of Ministers of the State Budget and supervise its execution. 
The amendments introduced in the Constitution in April $2003^{1}$ on the basis of a national referendum, defined constitutional and legal bases of formation and functioning of a bicameral parliament in Uzbekistan significantly expanded its supervisory powers. As the most important factor in ensuring parliamentary oversight, as enshrined in the Constitution, has served the norms on the responsibility of the Cabinet of Ministers in front of the Parliament. To the joint management of the both chambers of the Parliament has been attributed an authority to review and approve the candidacy of the Prime Minister upon the proposal by the President of the Republic of Uzbekistan - formerly Parliament had only approved the decree of the President of the Republic of Uzbekistan on the appointment of the prime minister. Another major form of parliamentary control that was introduced is the review of the Report of the Accounting Chamber.

The exclusive powers of the Senate - the upper house of parliament - was related to hearing of the reports of the Prosecutor General, the Chairman of the State Committee for Nature Protection, Chairman of the Board of the Central Bank. In addition, the Senate has the authority to appoint and release of diplomatic and other representatives of the Republic of Uzbekistan in foreign countries, to adopt the Amnesty Bill.

A logical continuation of reforms in the area of parliamentary control was the Concept of further deepening democratic reforms and formation of civil society in the country, adopted by the initiative of the first President of Uzbekistan Islam Karimov in $2010^{2}$.

Amendments introduced in accordance with the Concept in the Constitution of the Republic of Uzbekistan in $2011^{3}$ and $2014^{4}$, as well as in a number of other legislative acts adopted in the field of state-building, has ensured the further development of the constitutional and legal framework of parliamentary control mechanisms of checks and balances between the legislative, executive and judicial branches of government.

In accordance with these amendments to the Basic Law, there were introduced the procedure for the nomination of the Prime Minister by the political party that obtained the largest number of seats in the lower house of parliament, the non-confidence vote to the Prime Minister (article 98 of the Constitution), the parliamentary and public control (Art. 78.32 of the Constitution). The Parliament of the country have been provided with additional supervisory powers: a hearing and discussion of reports of the Prime Minister of the Republic of Uzbekistan on topical issues of socio-economic development of the country, consideration of the annual report of the Cabinet of Ministers on key issues of social and economic life of the country, and others.

All these innovations implemented in recent years have created the necessary conditions for the adoption in April 2016 of the Law "On parliamentary control" 5 (Hereinafter - the Law). This law consists of 28 articles, has incorporated the following main points:

The first. The law clearly defines the subject structure of legal relations in the implementation of parliamentary control. In particular, the subjects of parliamentary control defined are: The Legislative Chamber of the Oliy Majlis; The Senate of the Oliy Majlis; committees, commissions of the Legislative Chamber and the Senate; factions of political parties and parliamentary groups in the Legislative Chamber; Deputies of the Legislative Chamber; members of the Senate, as well as the Commissioner of the Oliy Majlis of the Republic of Uzbekistan for Human Rights (Ombudsman).

\footnotetext{
${ }^{1}$ See: Law of the Republic of Uzbekistan dated 24.04.2003 № 470-II «On introducing amendments and additions to the Constitution of the Republic of Uzbekistan" // Bulletin of Oliy Majlis of the Republic of Uzbekistan, 2003, number 3-4, Art. 27

${ }^{2}$ I.A. Karimov Concept of further deepening democratic reforms and formation of civil society in the country. URL: http://www.press-service.uz/ru/news/ 794 / (reference date: 06.09.2016).

${ }^{3}$ See .: Law of the Republic of Uzbekistan dated 18.04.2011, № ZRU-284 "On amendments and additions to certain articles of the Constitution (Articles 78, 80, 93, 96 and 98)" // "Bulletin of Oliy Majlis of the Republic of Uzbekistan », 2011, № 4, p. 102

${ }^{4}$ See .: Law of the Republic of Uzbekistan dated 04.16.2014, № ZRU-366 "On amendments and additions to certain articles of the Constitution (Articles 32, 78, 93, 98, 103 and 117)" // " Bulletin Oliy Majlis the Republic of Uzbekistan ", 2014, N 4, p. 85

${ }^{5}$ See .: Republic of Uzbekistan Act of 04.11.2016, № ZRU-403 "On parliamentary control" // "Collection of the legislation of Uzbekistan", April 18, 2016, №15, Art. 141
} 
Second. The Law regulates in detail questions about the object of parliamentary control. Also, it clarifies the coverage of the parliamentary control. Article 4 of the Law established that the main objective of the parliamentary control is to oversee the work of the government and management bodies and their officials on the implementation of the Constitution and laws of the Republic of Uzbekistan, decisions of the chambers of the Oliy Majlis of the Republic of Uzbekistan, state programs, as well as the implementation of related tasks and functions.

Analysis of the political and legal research shows that the most entrenched is the idea of parliamentary control, as an activity of the parliament to oversight the activities of executive bodies. In particular, the American scholar Joel Aberbah writes: "I define [oversight] as congressional review of the actions of federal departments, agencies, and commissions, and of the programs and policies they administer, including review that takes place during program and policy implementation as well as afterward"

International experience in the development of parliamentary shows that unreasonable, be it political or legal, expansion or contraction of the control powers of parliament can disrupt the balance between the branches of government, result in "the invasion" of each other's responsibilities with all the ensuing negative consequences. It is obvious, for example, that through the decision on the results of the parliamentary hearings on the course of implementation of laws, government programs in their respective areas of economic development, the Parliament should not replace the management body.

In this regard, the Law states that the objective of parliamentary control cannot be an activity related the overseeing the specific cases and materials that are under consideration of agencies, the interfering in the routine operational activities of investigation bureaus, the courts, as well as the materials of enforcement and notary proceedings. It was determined that in the exercise of parliamentary control legislative body should not interfere in the activities of bodies of state power and administration, other organizations and their officials carried out within their legitimate authority.

The study of foreign experience shows that the control limits are defined by two criteria or methods: laws where parliamentary control object clearly defined (legal aspect) and the scope of the principle of separation of powers, which clearly limits the scope of the constitutional powers of the parliament, the executive (political-legal aspect).

Third. The law clearly defines the forms of parliamentary control. Forms of parliamentary control are the outward expression of the political and legal content, which are understood as a set of internal components and processes that characterize parliamentary control, as a public-law institution, the most important function of parliament, an effective mechanism in the system of checks and balances between the branches of government.

The content of this political and legal mechanism composed under the influence of objective laws resulting from the degree of development of the society and its political institutions, and a number of other factors. Needless to state, the content of this phenomenon, i.e., parliamentary control, determines the choice of one or another of its forms. Although the form of any phenomenon or process (including parliamentary control) is relatively independent, defining a place in this unity of form and content belongs to the last ${ }^{7}$.

If these or other species that form the parliamentary control are fixed in law random, without regard to the state of the content, the level of development of the political and legal institution, it is the international practice, are these forms, or do not work, are not in demand, or a negative impact on order interaction between the legislative and executive branches of government.

In view of the above postulate, the Law explicitly stated thirteen basic forms of parliamentary control. These include: the adoption of the state budget; consideration of the progress of its implementation; consideration of the annual report of the Cabinet of Ministers on key issues of social and economic life of the country; hearing the report of the Prime Minister on the topical issues of socio-economic development of the country; hearing at the sessions of the Legislative Chamber of the Senate to the Government members on their activities; hearing the report of the Accounting Chamber; hearing the report of the Chairman of the State Committee of the Republic of Uzbekistan for

${ }^{6}$ Joel D. Aberbach, Keeping a Watchful Eye: The Politics of Congressional Oversight (Washington, DC: The Brookings Institution, 1990), p. 2.

${ }^{7}$ J. Tulenov system of laws and categories of dialectics. - Tashkent: Uzbekistan, 1974. - P. 295-296. 
Nature Protection; hearing the report of the Chairman of the Board of Central Bank of the Republic of Uzbekistan; Parliamentary deputy and inquiries; hearing the committees of the Legislative Chamber, Senate managers of state agencies and administration; study committees of the Legislative Chamber, the Senate of the state of enforcement of legislation, enforcement and monitoring of the adoption of the regulations; parliamentary inquiry; implementation of parliamentary control over the activity of the prosecutor's office and others.

Ensuring the rule of law in society, improving the efficiency of public administration, the maintenance of the stability of state power is impossible without effective law enforcement. On this basis, the Law (Article 19), pays special attention to the legislative establishment, the definition of the order of the parliamentary control over the activity of the Prosecutor's Office. It was established that for the implementation of parliamentary control over the activities of prosecutors, to improve the effectiveness of their efforts to ensure the rule of law in the country, to protect the rights and freedoms of citizens, interests of society and the state by the chambers of the Oliy Majlis, Senate commission is created to monitor the activities of the prosecutor's office. Senate annually at its meeting considers the report of the Prosecutor General of the Republic of Uzbekistan.

Fourth. The most important sign of the effectiveness of parliamentary control is the possibility of the Parliament on the results of audits of sanctions, i.e. various measures of the parliamentary response, entailing negative consequences of the objective of parliamentary control, failed to comply with legal requirements or efficiency of the policy of the state (no-confidence vote, the resolution of censure, etc.). It emphasizes the special role of the parliamentary opposition in the implementation of this function ${ }^{8}$.

According A.Zubareva, one of the purposes of parliamentary control is the focus of relevant government agencies and officials on identified during the parliamentary control deficiencies to correct them and bring the perpetrators to justice in accordance with the current legislation".

German scholar V.Steffani considers that parliamentary control is the process of verifying the parliamentary government and administration, with the direct (the parliamentary majority) and / or indirect (the opposition) the possibility of its approval or, on the contrary, criticism, evaluation, and application of sanctions or mandatory in legal terms the adoption of the government decision 10.

According to the American expert Walter J. Oleszek "A fundamental objective of congressional oversight is to hold executive officials accountable for the implementation of delegated authority. This objective is especially important given the huge expansion of executive influence in the modern era ${ }^{11}$.

Based on the above statements, it should be noted that the law clearly defined the necessary legal basis for the adoption of concrete measures of response by the results of the parliamentary control. So, it is established (Article 22 of the law) that the results of parliamentary control parliament within its power can:

* submit to the President of the Republic of Uzbekistan for the resignation of the Government member;

- make to the relevant public authorities proposals and recommendations for the adoption of measures aimed at improving the efficiency of enforcement of legislation, government programs, the implementation of their tasks and functions;

* return in the prescribed manner to public authorities reports made by them, reports, messages and other materials on completion indicating the comments and suggestions thereon;

* send the materials of the parliamentary control in the authorized state bodies for consideration in accordance with their powers;

* refer to the relevant government authorities and officials to take action on the immediate suppression of the detected violations of the rights and lawful interests of citizens or other violations of the law;

\footnotetext{
${ }^{8}$ Pelizzo R., Stapenhurst R. and Olson D. Trends in parliamentary oversight. World Bank Institute (2004) // URL: http://www.siteresources.worldbank.org

${ }^{9}$ Zubarev A.S. Control of the State Duma of the Federal Assembly of the Russian Federation for the activities of federal executive bodies: Diss. ... Cand. jurid. Sciences. - Belgorod: BGNIU, 2015. - S. 11.

${ }^{10}$ Steffani W.F. Verfahren und Wirkungen der Parlamentarischen Kontrolle // Parlamentsrecht und Parlamentspraxis in der Bundesrepublik Deutschland. - Berlin; N. Y., 1989. - S. 1325.

${ }^{11}$ Walter J. Oleszek. Congressional Oversight: An Overview // Congressional Research Service. 7-5700 URL: http://www.crs.gov.R41079 (дата обращения: 09.06.2016).
} 
* make to the relevant public authorities suggestions and recommendations to prosecute officials who release them from office;

* initiate the drafting of a new act of legislation or revision of existing legislative acts;

* publish the results of parliamentary control.

On the executive bodies of state power the following duties imposed (Article 23 of the Law):

* to ensure the review and execution of decisions taken by the subjects of parliamentary control;

* to develop the necessary measures and (or) to take decisions aimed at implementing the proposals and recommendations developed based on the results of parliamentary control;

* to inform the subjects of parliamentary control of the outcome of the proposals and recommendations and action taken thereon;

* to take action against officials of the government and management bodies for violation of the law.

In general, it should be stressed that the adoption of the Law "On parliamentary control" has become a logical continuation of the large-scale reforms and will contribute to strengthening the constitutional and legal capacity of the Parliament in the implementation of its tasks, strengthening and development of the democratic foundations of statehood and parliamentary system in the country. The process of implementing the provisions of the Law in national legislation and legal practice requires a thorough, fundamental theoretical scrutiny to disclosure of the nature, substance and content of the principles, mechanisms, forms and modern methods of implementation of supervisory authority of the chambers of the Oliy Majlis, as well as to conduct a broad outreach to bring the spirit and content of this law among the performers and the public.

\section{References:-}

1. Law of the Republic of Uzbekistan dated 24.04.2003 № 470-II «On introducing amendments and additions to the Constitution of the Republic of Uzbekistan" // Bulletin of Oliy Majlis of the Republic of Uzbekistan, 2003, number 3-4, Art. 27

2. Law of the Republic of Uzbekistan dated 18.04.2011, № ZRU-284 "On amendments and additions to certain articles of the Constitution (Articles 78, 80, 93, 96 and 98)" // "Bulletin of Oliy Majlis of the Republic of Uzbekistan », 2011, № 4, p. 102

3. Law of the Republic of Uzbekistan dated 04.16.2014, № ZRU-366 "On amendments and additions to certain articles of the Constitution (Articles 32, 78, 93, 98, 103 and 117)" // " Bulletin Oliy Majlis the Republic of Uzbekistan ", 2014, N 4, p. 85

4. Law of the Republic of Uzbekistan dated 04.11.2016, № ZRU-403 "On parliamentary control" // "Collection of the legislation of Uzbekistan", April 18, 2016, №15, Art. 141

5. I.A. Karimov Concept of further deepening democratic reforms and formation of civil society in the country. URL: http://www.press-service.uz/ru/news/ 794 /

6. Joel D. Aberbach, Keeping a Watchful Eye: The Politics of Congressional Oversight (Washington, DC: The Brookings Institution, 1990). - P.2.

7. J. Tulenov system of laws and categories of dialectics. - Tashkent: Uzbekistan, 1974. - P. 295-296.

8. Pelizzo R., Stapenhurst R. and Olson D. Trends in parliamentary oversight. World Bank Institute (2004) // URL: http://www.siteresources.worldbank.org

9. Zubarev A.S. Control of the State Duma of the Federal Assembly of the Russian Federation for the activities of federal executive bodies: Diss. ... Cand. jurid. Sciences. - Belgorod: BGNIU, 2015. - P. 11.

10. Steffani W.F. Verfahren und Wirkungen der Parlamentarischen Kontrolle // Parlamentsrecht und Parlamentspraxis in der Bundesrepublik Deutschland. - Berlin; N. Y., 1989. - S. 1325.

11. Walter J. Oleszek. Congressional Oversight: An Overview // Congressional Research Service. 7-5700 URL: http://www.crs.gov.R41079 